\title{
RELATIONSHIPS BETWEEN CZECH AND SLOVAK SCHOLARS BETWEEN THE YEARS OF 1850 AND 1882
}

\author{
Zuzana Kudzbelová \\ http://orcid.org/0000-0002-3593-233X \\ Matej Bel University in Banská Bystrica (Slovakia)
}

\begin{abstract}
Slovak scholars maintained close contacts with the Czech milieu in the $19^{\text {th }}$ century, for which there are several reasons (for example, the historical background, related to the issue of language and religion, the political situation in the Habsburg Monarchy). This paper sheds light on certain types of cooperation which took place between Czech and Slovak scholars between the years 1850 and 1882: cooperation in the field of journalism, publishing and editing the first Czech encyclopaedia.
\end{abstract}

Keywords: Czech-Slovak relationships, intellectual networks, $19^{\text {th }}$ century, Austrian Empire, Slovaks, Slovak national movement, Czech national movement.

In the $19^{\text {th }}$ century, Slav solidarity was one of the constant elements of the Slav national movements in the Habsburg monarchy. In every one of these movements, we can follow the increased interest in the fate of other Slavs, in what was happening in their environment and in the cultivation of personal and postal contacts. Slovak scholars maintained the most intensive contacts with the Czech national movement, for which there are several reasons.

The historical background, related to the issue of language and religion, played an important role here. In Upper Hungary, the official language was first Latin and, in the case of certain towns, German or Hungarian. Alongside these languages, Czech had begun to be used from the $15^{\text {th }}$ century and the language was adopted by Slovak Lutherans for the needs of their religious ceremonies. The similarity between the standard Czech of the time and various non-standard forms of Slovak led to the fact that Czech, in various Slovakicised forms, began to be used by Slovak scholars and clerks in administrative documents and in private correspondence. The use of Czech in the Slovak environment, and in particular its continued use by Lutherans in their services, led to a connection between the Czech and Slovak environments, which played an important role in the process of formation of the modern nations. As part 
of this, not only was the awareness of a Slovak ethnic particularity formed, but other alternatives, too, including the awareness of the unity of Czechs and Slovaks. Slovak Lutheran patriots considered Biblical Czech, which was their liturgical language, as the literary language of the Slovaks. For this reason, at the end of the $18^{\text {th }}$ century, they began to develop activities to defend the status of Czech, to strengthen its position in Slovakia and overall to cooperate more intensely with the Czech environment. Conversely, Slovak patriots of the Catholic faith, who were not so linked to the Czech lands, defended the Slovak particularity. Since the Slovak language existed only in the form of dialects and supra-regional literary forms, Catholic scholars decided at the end of the $18^{\text {th }}$ century to codify standard Slovak. However, this step did not meet with understanding from the Lutheran minority. ${ }^{1}$

Catholics represented the majority of the Slovak population, which was one of the reasons why towards the end of the first half of the $19^{\text {th }}$ century this awareness of the Slovak particularity was implemented in the Slovak national movement. This fact led to the conviction even among some of the Lutheran wing that there was a need for the Slovak language to be legislated for, which took place in 1843. Towards the end of the first half of the 19th century, the first political programme was formulated - the Žiadosti slovenského národa [Demands of the Slovak Nation] —which demonstrate the existence of the Slovak nation and its particularities. Although in various statelegislative concepts for the reconstruction of the Habsburg monarchy in the revolutionary years of 1848 and 1849 proposals for closer links between the Czech lands and Slovakia were made, they were only of secondary importance. In first place there was on the Czech side the attempt to create a constitutional federative Austria based on the principle of national equality, and on the Slovak side an attempt to federalize Hungary on the ethnic principle, followed by an attempt to separate the territory of Slovakia from Hungary and subject it to a central government in Vienna as a special autonomous unit.

Slovak and Czech scholars, however, even in the second half of the $19^{\text {th }}$ century did not stop maintaining and developing contact among one another. Towards the end of the $19^{\text {th }}$ century, it is possible to observe their strengthening lies, and thanks even to the activities of the the Detvan association and later the Českoslovanská Jednota [Czechoslav Unity], they took a certain institutionalised form. In my article, I focus on relations between Slovak and Czech scholars from 1850 to 1882, when they did not take on an organisational character. To date, it is Jarmila TkadlečkováVantuchová who has dealt with the Slovak-Czech relationship in the most detail during the period in question. In her monograph, she gave a detailed image of political relations between representatives of the Slovak and Czech national movement from 1850 to 1867 , and opinions on the mutual political cooperation between Slovaks and Czechs. ${ }^{2}$ The topic was later explored further by a study including the period

For more, see: A. Jarošová, "Prítomnost' češtiny na Slovensku a aspekt spisovnosti," Jazykovedný časopis 2016, no. 1, pp. 5-25; Dejiny Slovenska II (1526-1848), ed. V. Matula, Bratislava 1987, pp. 600-618.

2 J. Tkadlečková-Vantuchová, Česi a Slováci v národnooslobodzovacom boji do rakúskouhorského vyrovnania roku 1867, Bratislava 1970. 
following the Austro-Hungarian Compromise. ${ }^{3}$ From the non-political area of Czecho-Slovak relations in this period, so far the historians have mostly focussed on the issue of Slovak students or apprentices in the Czech lands, a subject dealt with by the authors František Hýbl ${ }^{4}$ and Zdeněk Fišer. ${ }^{5}$ It was in fact Fišer who made a significant contribution to describing the personal relations between certain Slovaks and Moravians, for example by publishing the correspondence between Daniel Sloboda and Jozef Miloslav Hurban ${ }^{6}$ or between Alois Vojtěch Šembera and Slovaks. ${ }^{7}$ The present study sets out to present the reader with certain types of cooperation which took place between Czech and Slovak scholars in the period in question, and which have not yet been much studied. This concerns cooperation within the field of the press, publishing activities and the first Czech encyclopaedia.

\section{DIFFERENCE IN THE ORGANISATIONAL BACKGROUND OF THE SLOVAK AND CZECH NATIONAL MOVEMENT AND POLITICAL DEVELOPMENTS IN HUNGARY AND THE CZECH LANDS}

As well as the above-mentioned historical background, the development of relations between Czech and Slovak scholars in the 1850-1882 period was undoubtedly influenced by the political situation within the Habsburg monarchy. The latter was unfavourable to the Slovak national movement, which led to the fact that it was unable to assert itself significantly, with the exception of the 1860s. The Czech national movement, however, began to gain in strength gradually. This was without doubt influenced by the fact that the Czech national movement had entered the second half of the $19^{\text {th }}$ century already with a certain organisational background. In 1818, the Vlastenecké muzeum v Čechách [Patriotic Museum in Bohemia] was founded in the Czech lands, within which the Sbor $k$ védeckému vzdělávání reči a literatury české [Association for the Scientific Education of the Czech Language and Literature] was created in 1830. It was responsible for the foundation of Matica česká one year later. The latter took on the publication of the museum's journal which became a very

3 J. Tkadlečková-Vantuchová, "K problematike československých vzt’ahov po rakúskomuhorskom vyrovnaní (1867),” Historický časopis 1970, vol. 18, no. 2, pp. 195-221.

4 F. Hýb1, "Slovenští studenti na moravských středních školách v 19. stoletî” [in:] Česko-slovenské vztahy v oblasti školství, ed. F. Hýb1, Přerov 1994, pp. 65-72.

5 Z. Fišer, "Biografický přehled slovenských žáků na gymnáziu v Přerově v letech 1875-1916" [in:] Sborník Státního okresního archivu Přerov, ed. J. Lapáček, Přerov 2016, pp. 37-70; Z. Fišer, "Profesor Ĺudovít Čulík a jeho slovenští žáci na gymnáziu v Přerově v letech 1875-1880: ke 120. výročí vzniku Jednoty českoslovanské podporující zájmy Slováků a Slovenska," Vlastivědný věstník moravský 2016, no. 3, pp. 238-252.

6 Z. Fišer, Dokumenty. 4. Korespondence Daniela Slobody s Jozefem Miloslavem Hurbanem, Brno 2009.

Z. Fišer, Korespondence Aloise Vojtěcha Šembery, sv. 5: Listy slovenským práteliom, Vysoké Mýto 2007. 
influential periodical of the Czech national movement. The first Czech associations were founded, for example in 1846 the representative centre for Czech entrepreneurs and scholars, the Měśtanská Beseda, and the number of publishing houses, bookshops and municipal schools also grew ${ }^{8}$. In the first half of the $19^{\text {th }}$ century, quite a well-developed network of Czech institutions was formed, on which the representatives of the Czech national movement could rely to achieve their further objectives. In addition, in the 1840s, a group of Czech personalities was formed around František Palacký and František Ladislav Rieger, which kept alive Czech national life during the period of neo-Absolutism. Partially thanks to this, the Czech national movement was able to found its official political body as early as 1860, the Národni strana [National Party], which made demands for the representation of the whole Czech nation'.

The construction of an organisational centre for the Slovak national movement took place with many interruptions. The Tatrin association was founded in 1844, bringing together representatives of the Slovak national movement, but it existed only for a short time, until 1848. Slovak nationalists ${ }^{10}$ only succeeded in building a wider organisational base at the beginning of the 1860s. In 1861, they began to publish Peštbudinke vedomosti, which became the printed organ of the main tendency in the Slovak national movement. In 1863, a nationwide and supra-faith Slovak cultural institution was founded-Matica slovenská — which aimed to raise in Slovakia's common population an awareness of belonging to the Slovak nation, and to support the artistic and scientific activity of Slovaks. At this period, the socio-political situation was also favourable to the development of the teaching of Slovak in schools, to the foundation of three new Slovak grammar schools and the overall wide-ranging invigorating of the national and cultural life of Slovaks. However, the Austro-Hungarian Compromise of 1867 interrupted this gradual blooming of the Slovak national movement, and signalled not only an end to the hopes for meeting its further political and cultural demands, but also the destruction of the pillars that had already been built. After 1867, the idea of recasting Hungary into a single ethnic Hungarian state was definitively implemented. Even though Hungarians did not make up the majority of Hungary's population, it was set down in law that only one nation existed on its territory - the Hungarian nation, and other ethnicities were given only the status of ethnic group. Hungarian became the official state language. The nationality law from 1868 did enable non-ethnic Hungarians to use their mother tongue in official communication at a municipal level, or at the level of local county government, and to establish primary and second schools or institutions for the development of their culture, but in practice this was not respected. From 1867, Slovaks, just like other ethnicities within Hungary, began to face intense pressure from Magyarisation in all aspects of their lives. In Cisleithania, no viable conception of an Austrian nation state was created; for this reason, the principles of ethnic equality declared in 1848 were

J. Kořalka, Češi v habsburskej řiši a v Evropě 1815-1914. Sociálněhistorické souvislosti vytváreni novodobého národa a národostni otázky v českých zemích, Praha 1996, pp. 91-105.

9 M. Hlavačka [et al.], České země v 19. století. Proměny společnosti v moderni době. II, Praha 2014, pp. 34-42.

10 In the sense of members of the Slovak national movement. 
applied to everyday life without great difficulty. Thanks to this, Czech national life, unlike its Slovak equivalent, continued to blossom.

\section{CZECH PERIODICAL PRESS}

For this reason, Slovak scholars resorted to Czecho-Slovak solidarity, and under its patronage, they looked for support for their efforts within the Czech lands. For example, one of the means which they used to put across their opinions on the development of relations in the empire - in Hungary — on the issue of the Slovak nation and to spread awareness of the Slovak nation was the Czech periodical press. The establishment of Slovak newspapers took place without any continuity. In 1783, the Prešpurské noviny began to be published as the first ever Slovak newspaper, followed in 1812 by another Slovak periodical, Týdennik, but due to a lack of readers, they did not last long. After their discontinuation, until the mid-1840s almanacs took on the role of Slovak newspapers insofar as their limits allowed (for example Zora, Plody, Jitřenka), together with literary magazines (e.g. Tatranka, Hronka). Slovaks could publish texts of a political nature after the establishment of the first Slovak political newspaper-Slovenskje národñje novini - in 1845. The function of mouthpiece for the Slovak national efforts was also held to a certain extent by Slovenský pozorňik. Both periodicals stopped being published in 1848. From that moment until the beginning of the publication of the above-mentioned Pešt'budinskych vedomost $i$ in March 1861, there was no politically independent daily newspaper in the Slovak national movement. Slovak nationalists could only react to social events in literary and cultural magazines (for example Slovenskje pohladi na vedi, umeňja a literatúru, Priatel' školy a literatúry), but only to a very limited extent, due to their nature. ${ }^{11}$

In the 1850s, not even the Czech national movement had a political newspaper, but it did react much quicker to the changing socio-political situation in the Habsburg monarchy at the end of the 1850s; as a result, in July 1860 Alois Krása began to publish the Czech political newspaper Čas. From January 1861, Julius Grégr published the daily Národní listy and in April of the same year, the weekly Obecné listy was founded. In 1862, the political daily Hlas was founded by Vincent Vávra, which merged three years later with Národni listy. ${ }^{12}$ In Moravia, Moravan was founded in 1862, but discontinued shortly after, and in 1863, Moravská Orlice began to be published..$^{13}$ Of course, it was not only the number of political publications that grew, but also literary, humoristic, scientific and economic-educational periodicals.

11 W. Duchkowitsch, D. Serafínová, J. Vatrál, Dejiny slovenského novinárstva. Vývoj novinárstva na Slovensku v kontexte podunajskej monarchie, Ružomberok 2007, pp. 139-155.

12 F. Roubík, Časopisectvo v Čechách 1848-1862, Praha 1930, pp. 59- 95.

13 J. Kubíček, Noviny a časopisy na Moravě a ve Slezsku do roku 1918. Literatura a prameny, sbirky, bibliografie, Brno 2001, p. 4. 
It was in fact Czech newspapers which gave Slovaks the space for expressing their opinions. $\check{C}$ as became the main tribune for Slovaks. They used it to try and inform about the socio-political situation in Hungary, the status of Slovaks, the Slovak national gathering in Turčiansky sv. Martin, Matica slovenská, or other activities of the Slovak national movement, and to point to the attempts to Magyarise schools or institutions in Slovakia. ${ }^{14}$ Since the number of articles by Slovaks grew and Čas was not able to publish them all, its editorial board decided to publish them in a special publication Hlasy Slovákưv [Voices of Slovaks] with the financial support of the Prague benefactor Ferdinand Pravoslav Náprstek ${ }^{15}$.

Even though the Slovak periodical press did gradually register a boom in the course of the 1860s, nevertheless Slovak nationalists continued to use Czech newspapers. One of the reasons for this was the dissension within the Slovak national movement, which first expressed itself openly at the Slovak national gathering in June 1861, where it decided on the future political progress of the Slovaks. The latter was officially presented in the Memorandum slovenského národa [Memorandum of the Slovak Nation]. Against this programme an opposition political tendency, the socalled Nová škola [New School] was formed, which considered some of the demands and objectives it contained as unrealistic. Above all its supporters did not agree with the orientation of Slovak politics towards imperial Vienna and the demand to create a so-called slovenské Okolie [Slovak Vicinity]. On the contrary, they defended Vienna's creation of an independent Hungary, where Slovaks would be allowed to develop their own culture and use the Slovak language in institutions. The voice of the political line pushing forward the memorandum, also known as the Stará škola [Old School] or Martin wing, was the Pešt tbudinske vedomosti, and for this reason the Nová skola could express its opinions only in the cultural magazine, the Priatel' školy a literatúry, which was edited by one of its supporters, Andrej Radlinský. In 1861, however, he had to end its publication. Until the Nová škola established its own press institution in 1868 (Slovenské noviny), it tried to a great extent to use the Czech political press to spread its opinions. Later, this applied mainly to the press of the new political tendency in the Czech lands, which had broken off from the Národni strana: the Mladočeši [Young Czechs]. ${ }^{16}$ At first, the Nová škola and Mladočeši were linked by similar views on the political life of the Habsburg monarchy, in particular a positive relation to the liberal wing of Hungarian politics. They put forward their

14 For example: Anon., "Chováni Mad’arů k Slovaků," Čas, vol. 2, 6 I 1861, p. 2; Anon., "Stav Slovaků v Uhersku a jejich potřeby," Čas, vol. 2, 9 II 1861, p. 2; Anon., "Národní shromaždění Slovákův v Turčianském sv. Martine," Čas, vol. 2, 14 VII 1861, p. 2; A non., "První základy Matice slovenské.“ Čas, vol. 2, 27 VIII 1861, p. 3.

15 Hlasy Slovákův, Praha 1861.

16 This political grouping did not agree with the non-participation of Czech politicans and the historic aristocracy in the Imperial council and in the Czech parliament at the beginning of the 1870s, which was implemented by the Národni strana [National Party]. They assumed that active politics would be more purposeful from the point of view of the economic prosperity of the Czechs. They considered passive resistance as a tool which would lose them influence in education, decision-making on tax issues and they would lose their influence on the chamber of industry and commerce. For more, see: O. Urban, Česká společnost 1848-1918, Praha 1982, pp. 192-263. 
attitudes, for example, in the pages of Hlas. In several of their texts, emphasis was placed on faith in the peace-loving cohabitation between Hungarians and Slovaks within the joint state of Hungary, Hungarians were called the brothers of Slovaks, or the Hungarian journals Pesti Napló, Ország and Jövö were evaluated positively. ${ }^{17}$ After the merger between Hlas and Národní listy in 1868, articles by the Nová škola can also be found in this periodical, too. However, Národní listy continued to provide publication space for its opposition, too - to the Martin wing, which did not want to leave the articles by the Nová škola unanswered. This tendency in the political representation of Slovaks also used other Czech newspapers to express their opinions in the Czech environment, for example Posel z Prahy, Národ, Národní Pokrok, Čech, the media of the Staročeši [Old Czechs], whose opinions were close to their own, even though their relations were not without complications.

The significance of Czech newspapers for the Slovak national movement also had a second dimension. Since from the mid- 1860s, the implementation of the AustroHungarian Compromise was becoming more and more of a real prospect, certain representatives of the Czech national movement expressed an interest in the Slovaks as in an ally in their attempt to emancipate their national status. For this reason, they took an open and positive stance on the latter's national emancipation efforts. Not only did they offer them space more frequently in the pages of their press, but they also borrowed articles from Slovak newspapers and published texts on the Slovak question, which helped the Slovak national movement spread awareness of its status, activities and objectives. ${ }^{18}$ The importance of this type of help was highlighted in particular after the Austro-Hungarian Compromise. After 1867, the Press Act from 1852 once again entered into force in Hungary, which meant increased censorship and thus persecution for opinions which were not in accordance with the idea of a unified Hungarian nation. State measures led overall to a paralysis in the political, cultural, and social activities of the Slovak national movement. During this period, it was the Czech press that became one of the bearers of information on the ethnic status of the Slovaks within Hungary and on the various forms of Magyarisation.

Czech scholars only rarely contributed to Slovak newspapers. At the turn of the 1860 s, however, we can note the efforts made by certain political representatives of the Czech national movement to come closer to the Slovaks, including in the field of the press. For example, F.L. Rieger wanted to begin publishing a Czech political newspaper in Slovakia. However, J.M. Hurban did not see this act in a positive light and in his reply, he wrote to Rieger that there was no-one in Slovakia willing to become an editor of such a newspaper. ${ }^{19}$ Vincent Vávra, the editor of Hlas at the time,

17 Articles from Slovakia was anonymous, but their content points to the fact that their authors might have included supporters of the Nová škola. For example: Anon., "Ze Slovenska," Hlas, vol. 1, 20 XI 1862, p. 1; Anon., "Ze Slovenska," Hlas, vol. 1, 20 XII 1862, pp. 2-3; Anon., "Politika Slováků má býti smělá a př́ma," Hlas, vol. 2, 30 XII 1863, p. 2.

18 The rise in the number of articles about the Slovak issue can be seen in the pages of several Prague newspapers from 1865, in particular in Národni listy and Národ.

19 Literary Archive of Slovak National library, Jozef Miloslav Hurban Collection, F.L. Rieger to J.M. Hurban, 6 III 1860. 
also decided to address J.M. Hurban in a letter, offering him the opportunity to write in his journal about the Slovak nation, its needs, plans or problems. He pointed to the stagnation in the development of relations between Czechs and Slovaks and expressed the wish for his periodical to become, with the help of contributions from Slovaks: "[...] a true «voice» for the whole Czecho-Slovak nation, the Voice of a nation of seven million people in Bohemia, Moravia, Silesia and Slovakia”. Vávra mentioned to Hurban that he would be willing to publish articles from other Slovaks about the situation of the Slovak nation in a special publication, similar to that of $1861,{ }^{20}$ but in the end this did not come about. The Czech political elite at that time was aware of the fact that the Habsburg monarchy needed to carry out a fundamental reform of its management. With the renewal of constitutional relations, various concepts for resolving individual ethnic issues appeared. In their political demands, Czech scholars followed on in various aspects from the years 1848/1849. Since at the beginning of the 1860s it was still not clear as to how the reform of the Habsburg monarchy would be carried out, at first the elites in Czech political life placed an emphasis of CzechoSlovak national unity and repeatedly revived the idea of Austro-Slavism, to which the above-mentioned initiatives by Rieger and Vávra were also linked.

\section{CZECH PUBLISHING HOUSES AND PRINTERS}

The relatively developed institutional background which was available to the Czech national movement in the second half of the $19^{\text {th }}$ century meant that Slovak scholars made contacts not only with Czech cultural organisations, becoming their founding members, but also with Czech publishing houses and printers. Through them, they tried to cultivate Slovak culture, in the sense of a set of works of a literary, musical, artistic and scientific nature, because they saw in them (as did representatives of other national movements) the expression and evidence of their national autonomy. They thus added to the activities of printing and publishing houses in the service of the Slovak national movement such as the Machold or Škarnicel publishing and printing house, and from 1869 the Kníhtlačiarsky účastinársky spolok [Letterpress shareholder association].

In the 1850s, the liveliest contacts were with Matica česká. In 1854, its members included 50 Slovaks. They were mainly linked through the professor of Slav studies at Prague University, Martin Hattala, who was in charge, inter alia, of the distribution of its book production in Slovakia. Matica česká published the work by L'udovít Štúr $O$ národních písních a pověstech plemen slovanských [On national songs and legends of the Slav races] and Hattala's work Zvukosloví jazyka staro- i novo-českého a slovenského [Phonetics of the old and new Czech and Slovak language]. Hattala published in Prague in 1857 Srovnávací mluvnice jazyka českého a slovenského

20 Literary Archive of Slovak National library, Jozef Miloslav Hurban Collection, Hlas to J.M. Hurban, 18 X 1860. 
[Comparative grammar of the Czech and Slovak language] at the cost of the J.G. Calve university bookshop.

Slovak scholars cooperated with the important Prague publishing house of Ignác Leopold Kober, which became a sought-after centre for Czech writers in the 1860s. It published, for example, the historical novella Gottšalk by J.M. Hurban ${ }^{21}$ and the memoirs of J. Kollár. ${ }^{22}$ Kober also decided to publish the first Czech encyclopaedia, which played an important role in the Slovak national movement, and to which I will devote the next section of this text. As a result of I.L. Kober's sudden death in 1866, Fratišek Augustín Urbánek administered the company managing Kober's publishing house until his son Karol Bohuš Kober reached adulthood in 1870. In that period, he himself was striving for closer cooperation with the Slovaks, which was related to his strong awareness of Czech-Slovak solidarity. As part of the Národni bibliothéka [National Library] series, he wanted to publish the works of the "leading CzechoSlav writers". From the Slovak authors, he planned to edit a selection of works by A. Sládkovič, J. Botto, J. Slota and V. Pauliny-Tóth. Urbánek offered the editing of the Slovak part of this series to the Slovak Catholic priest Michal Chrástek, because in his opinion he had a good reputation both in Slovakia and in the Czech lands. ${ }^{23}$ He succeeded in publishing a selection of works by A. Sládkovič ${ }^{24}$ and J. Slota. ${ }^{25}$ In both collections, an extensive biography of the author was provided, together with a portrait.

In 1872, Urbánek founded his own publishing house and began to publish original literature for children and young people, teaching guides and teaching aids. ${ }^{26}$ As part of this, he continued in his attempts to maintain wider contacts with Slovak scholars. In addition to supporting significantly, for example, Slovak libraries with books from his publishing house, ${ }^{27}$ during the period concerned by this study he also published works by two important representatives of the Slovak national movement.

This concerned Ján Gerometta, whose Aeltere und neuere Magyarisirungs-Versuche in Ungarn, mit besonderer Rücksicht auf die Slovaken was published by Urbánek in 1876. With this work, Gerometta decided to introduce the wider public to the politics of the Budapest government which had ordered the closure of the Slovak grammar schools, the sole Slovak institution of Matica slovenská, and had prevented the activities of representatives of the Slovak national movement. In eight chapters, he described the phases of the process of Magyarisation in the Slovak environment,

21 J.M. Hurban, Gottšalk. Dějepisná pověst z IX. století, Praha 1861.

22 J. Kollár, Cestopis obsahujicí cestu do Horni Italie a odtud přes Tyrolsko a Bavorsko se zvláštním ohledem na slavjanské živly roku 1841 konanou a sepsanou od Jana Kollára, Praha 1862.

23 Literary Archive of Slovak National library Ján Botto Collection, F.A. Urbánek to J. Botto, 14 IV 1868

24 A. Sládkovič, Andreja Sládkoviča Spisy básnické, Praha 1878.

25 J. Slota, Jiřiho Sloty Rajeckého Básnické spisy, Praha 1882.

26 Lexikón české literatury. Osobnosti, díla, instituce, sv. 4/II: U-Z, ed. V. Forts, Praha 1993, pp. 1129-1130.

27 Š. Pasiar, Dejiny slovenských l’udových knižnic, Martin 1957, pp. 109, 110, 113, 116. 
namely in the period ranging from the 1830 s to Gerometta's own day. ${ }^{28}$ Urbánek decided to publish this work, despite being afraid of its confiscation due to its content. This did not actually happen, but in the end demand was not high, a fact about which Urbánek complained to his Slovak friend L'udovít Rizner. ${ }^{29} \mathrm{He}$ had assumed that larger numbers of Slovaks would have supported him by buying it. Since the work criticised the Budapest government and was in conflict with its political stance, many Slovak scholars decided not to buy it, probably out of fear of persecution. ${ }^{30}$

In cooperation with the Czech bookseller F. Brožík, Urbánek also published the work by Samuel Dobroslav Štefanovič Die Slaven und die Nationalitätenfrage: gedankenskizze von einem Slovaken. It dealt with the status of the Slavs within the Habsburg monarchy and criticised the socio-political situation of the time. In his work, Stefanovič tried to explain the absurdity of the unfair prejudice against the Slavs, who due to their differing - often even contradictory-interests could not form in his opinion any real force within the Habsburg monarchy, as was often presents in the press. For this reason, he also refused all suspicions of organising a secret revolution of Slavs. In his work, he also pointed to the Hungarians and their advantageous position obtained within the empire, despite being the instigators of the revolution in Hungary from 1848 to 1849 . In contrast, the Austrian Slavs had not only not been rewarded for their loyalty, but they had even been treated as enemies of Austro-Hungary. ${ }^{31}$ Shortly after the publication of his brochure, however, it appeared that certain opinions contained in it were not only in conflict with the opinion of the Hungarian national movement, but also incurred the disfavour of the imperial institutions and it became illegal to distribute his brochure in any manner. The public was informed about this by the "Prager Abendblatt". ${ }^{32}$ Urbánek informed Štefanovič about this in writing ${ }^{33}$ and subsequently sent him the above-mentioned notice from the law and order police in Prague containing the justifications for the ban on distributing the brochure, which included: an insult to members of the royal family, disturbance to public order through a call to express contempt and hate for state institutions and the public shaming of the institution of the family. ${ }^{34}$

From the 1870s, the Slovak national movement remained paralysed and any expressions of opinion which did not match the political line of the then ruling

28 T. Adamčík, Bratia Eugen a Ján Geromettovci v slovenskom národnom hnutí. Dizertačná práca, Banská Bystrica 2016, pp. 124-130.

29 Literary Archive of Slovak National library, Ludovít Vladimít Rizner collection, F. Urbánek to L'.V. Rizner, 7 II 1886, 18 VIII 1886.

30 Gerommetta also published his second work with Urbánek, in which he tried to present to the wider public the Magyarisation of the church in Hungary, which the Budapest government used to try to Magyarise non-Hungarian nations. However, this work was only published in 1886.

31 Literary Archive of Slovak National library, S.D. Štefanovič Collection, Slaven und die Nationalitätenfrage, $44 \mathrm{pp}$.

32 Prager Abendblatt, vol. 14, 18 X 1880, p. 3.

33 Literary Archive of Slovak National library, S.D. Štefanovič Collection, F.A: Urbánek to S.D. Štefanovič, 20 XI 1880.

${ }^{34}$ Literary Archive of Slovak National library, Brožík Franz et. Comp. K.K. Landesgericht in Prag, 1880 . 
Hungarian party were unacceptable. In the event of the publication of this type of political work, a sanction would fall not only on the author himself, but also on the publisher or printer. For this reason, they also published their works anonymously.

Urbánek, however, began to support Slovak literature on his own initiative. By the end of the 1870s, he was already thinking about publishing some Slovak works as part of his series Nová knihovna pro mládež [New library for young people]; ${ }^{35}$ this only happened, however, in 1886. It is worth mentioning the initiative by the Czech publisher and writer Eduard Valečka, who published in 1865 Staré a noví piesne [Old and new songs] by an important representative of the Slovak national movement, V. Pauliny-Tóth. In the introduction to this collection, he called in fact on Slovaks and Czechs not to descend into pointless disputes. In his opinion, they needed to join together once more in their political and literary activities in order to avoid repeating the event of one thousand years before, when the Czechs and Slovaks fell to their Hungarian and German opponents due to their own lack of union. By publishing the poems by Pauliny-Tóth, he tried to deepen the idea of Czecho-Slovak solidarity. ${ }^{36}$ This effort was also linked to his strong awareness of Czecho-Slovak and Slav solidarity, which was also expressed in his further activities; for example, publishing in Slovak. ${ }^{37}$

In addition to the above-mentioned works, from 1850 to 1882 , further original Slovak works or translations into Slovak were published by other Czech publishing houses, booksellers and printers, for example a brief overview of the history of Slovakia by S.A. Osvald, ${ }^{38}$ the play Jánošik by M. Skačanský, ${ }^{39}$ and various text books in Slovak. ${ }^{40}$

\section{SLOVNÍK NAUČNÝ}

Slovak scholars also joined in with the compilation of the first Czech encyclopaedia-Slovnik naučný - which began to be published from 1859. It was a national encyclopaedia which was intended to prove the maturity of the Czech nation and provided information in Czech about the nation and its country. The entries in it mainly referred to historical moments, personalities and the geographical area to which

35 Literary Archive of Slovak National library, L'V. Rizner Collection, F. Urbánek - L.V. Rizner, 21 V 1877.

36 V. Pauliny-Tóth, Staré i nové piesne V. Podolského, Praha 1866, pp. 1-4.

37 Literary Archive of Slovak National library, P. Dobšinský Collection, E. Valečka to P. Dobšinský, 4 XII 1860.

38 S.A. Osvald, Krátučký prehl'ad dejín Slovenska od najstaršej až do najnovejšej doby pre l’ud obecný, Praha 1867.

39 M. Skačanský, Jánošík, Praha 1880.

40 K. Hübner, Počtovanie na obrazoch, Praha 1872; J.F. Strakovič, Krátke poučenie o hospodárstve a rolnictve, Praha 1864; A. Pokorný, Dra A. Pokorného Obrázkový prírodopis všetkých troch rís. Prvýdiel, Obrázkový prírodopis živočíšstva, Praha 1875. It was translated into Slovak by G. Kordoš. 
Czech scholars at the time ascribed the greatest important. In the Czech environment, the Catholic priest František Faistin Procházka, and later the philologist Jozef Jungmann, had considered the creation of a systematically arranged work of information, but in both cases, it was intended to be a work of compilation. The first initiative for the creation of an original Czech encyclopaedia appeared towards the end of the 1820s, and one of the most significant personalities in Czech social life-František Palacký - was behind this idea. Already in the initial phases of the preparation of this work, Palacký asked several Slovaks to cooperate, namely Ján Kollár, L’udovít Štúr, Gašpar Fejérpataky-Belopotocký, Pavol Jozef Šafárik ${ }^{41}$ and K. Kuzmány. ${ }^{42}$

However, due to the lack of time of his collaborators and financial problems, Palacký failed in his aim. He tried to revive his encyclopaedia project at the beginning of the 1850s. At this time, Palacký asked once more the Slovak Lutheran pastor Karola Kuzmány, who was then working as a professor of theology at the university in Vienna, for cooperation in compiling the encyclopaedia. Kuzmány accepted his offer, sent him a list of entries from A to Č, which he believed should be included in the encyclopaedia. The correspondence shows that Kuzmány at the time had written at least 45 entries. ${ }^{43}$ However, the encyclopaedia only came into being at the end of the 1850 s, thanks to František Ladislav Rieger, whom the encyclopaedia is usually named after. Rieger succeeded in concluding a contract with the publisher I.L. Kober and obtaining the collaboration of a greater number of scholars on this publication. Work on its compilation began in 1858; the last, eleventh volume, was completed in 1874. The Názornýatlas $k$ Slovníku naučnému [Illustrations to accompany the encyclopaedia] was published alongside the basic work, and in 1889 a volume of addenda and corrections was published.

Only incomplete information existed about Slovaks in German or Hungarian dictionaries, often with various errors. However, Slovak scholars at that time were not yet capable of publishing such a demanding type of work, ${ }^{44}$ therefore several of them accepted the opportunity to work on entries concerning the Slovak environment for the Czech encyclopaedia. This involved specifically Jozef Miloslav Hurban, ${ }^{45}$ Karol Kuzmány, Michal Chrástek, Samuel Chalupka, Ctiboch Zoch, František Vítazoslav Sasinek and Ludovít Rizner. At the same time, the general Hungarian encyclopaedia also began to be published-Egyetemes magyar encyclopaedia, and for this reason the most active contributor from Slovakia, the Catholic priest Michal Chrástek,

41 S.B. Winters, "Sto let českého encyklopedismu (1860-1959): od F.L. Riegera a Jana Otty k T. G. Masarykovi a Bohumilu Němcovi," Časopis Matice moravské 2002, no. 2, pp. 339-400; R. Dvořák, "Snahy Františka Palackého o vydání české encyklopedie" [in:] Památník na oslavu stých narozenin Františka Palackého, ed. V.J. Nováček, Praha 1898, pp. 341-366.

42 F. Čenský, Z dob našeho probuzení. Sbirka prátelských dopisů, Praha 1875, p. 40.

43 The Museum of Czech Literature Literary Archive, František Palacký Collection, K. Kuzmány to F. Palacký, 18 VI, 20 VI, 20 XII 1851, 2 II 1852.

44 The first Slovak encyclopaedia was compiled by Pavol Bujnák in 1932. Slovenský náučný slovník. I-III, ed. P. Bujnák, Bratislava 1932.

45 For more, see: Z. Ku dzbelová, "Prispievatel'ská činnost' J.M. Hurbana v (Riegrovom) Slovníku naučnom” [in:] Jozef Miloslav Hurban - osobnost' v spoločnosti a reflexii, eds. P. Macho, D. Kodajová, Bratislava 2017, pp. 251-264. 
warned F.L. Rieger of this fact and asked him not to shorten his entries on Slovak themes and to publish them in as much detail as possible. In his opinion, this would also ensure a higher number of purchasers for the encyclopaedia in Slovakia. ${ }^{46}$ Several representatives of the Slovak national movement undoubtedly regarded the Slovnik naučný as one of the forms of defence against the repression of the awareness of the Slovak nation by the Hungarian national movement. Partly for this reason, it concentrated within it a large quantity of information defining the important figures, places and historical events of the Slovak nation.

It was probably the increase in Magyarisation activities in Hungary after the Austro-Hungarian Compromise that led to there being no Slovak present among the contributors by the beginning of the 1870s. Perhaps the problems such as the closure of the Slovak grammar schools or squeezing out the Slovak language from schools took up the attention of Slovak scholars to such an extent that they no longer had any energy for the Slovnik naučný. Some entries concerning Slovakia, however, were prepared by Czechs. For example the entry on important Slovak historical figures such as Ludovít and Karol Štúr was drawn up by a teacher at a forestry school in Mariabrunn near Vienna, Karel Schindler. The above-mentioned F.A. Urbánek wrote new, or expanded existing entries with over ten important Slovak figures.

Despite the lack of activity of Slovaks in the latter volumes of Slovnik naučny, the latter without any doubt played a very important role in the Slovak National Movement. For the first time, the Slovnik náučný provided a space in which a large amount of information which defined the important figures, places and historical events of the Slovak nation, was brought together in one place. It published the first biographies of the majority of Slovak personalities. The encyclopaedia was also one of the means for defining the territory of Slovakia. In it we discovered which towns, mountains or areas were given the most importance by Slovak scholars at the time. There is information, for example, on Banská Bystrica, Nitra, Trenčín, Martin, Zobor, Devín, the Hron and the Váh rivers. The entries allow us to identify specific historical topics which attracted their attention, or which they considered to be key from the point of view of the development of the Slovak nation. This mainly concerned the period of the Nitra principality and the rule of Matúš Trenčiansky, as well as the figures of Matej Bela and the first kings of Hungary.

$$
* * *
$$

In the first three decades of the second half of the $19^{\text {th }}$ century, we can follow the wide-ranging publishing activity of Slovaks in Czech periodicals. Slovak scholars made contact with the editors of several Czech periodicals, because they were using them to try to put across their opinions on the situation in Hungary, the Habsburg empire and in Slovakia, and to inform the wider public about their objectives, opinions and activities, a need due to both to a certain delay in the publication of political

46 The Archive of the National Museum, Prague, František Rieger Collection, Folder 3, Michal Chrástek to František Ladislav Rieger, 22 III 1860. 
periodicals in Slovakia, to their small number and also after 1867 to the fact that it was impossible to publish freely in them. During the period studied, the relations of Slovak scholars with Czech publishers and printers also grew. In this way, they tried to add to and, after 1867, to replace the activities of Slovak publishers and printers which began to be limited in their activity after the Austro-Hungarian Compromise. When mapping out these relations, we can also observe that among the Czech scholars and booksellers there were also individuals who had a strong awareness of Czecho-Slovak closeness, and therefore also published on their own initiative certain Slovak works, trying in this way to strengthen Czecho-Slovak solidarity, as was the case for example with F.A. Urbánek and E. Valečka. Another interesting collaboration between Czech and Slovak scholars in the field of compilation and publishing activities was the participation by Slovaks in entries on Slovak realia in the first Czech encyclopaedia. Thanks to this, the wider Slovak and Czech public found out about Slovaks, Slovak culture, the Slovak lands and Slovak history more extensively, and they were thus given an alternative to information about Slovakia and Hungary obtained from Austrian, German and Hungarian lexicons.

\section{BIBLIOGRAPHY}

\section{Historical sources}

\section{Archive sources}

Literary Archive of Slovak National library, Martin, Slovakia Ján Botto Collection.

Jozef Miloslav Hurban Collection.

Ludovít Rizner Collection.

Pavol Dobšinský Collection.

Samuel Dobroslav Štefanovič Collection.

The Archive of the National Museum, Prague, Czech Republic František Rieger Collection.

The Museum of Czech Literature Literary Archive, Prague, Czech Republic František Palacký Collection.

\section{The press}

Čas 1860-1862.

Čech 1864-1865.

Hlas 1862-1868.

Národ 1863-1866.

Národní listy 1861-1880. 
Národni Pokrok 1867-1868.

Posel z Prahy 1870-1877.

Prager Abendblatt 1880.

\section{Other sources}

Adamčík, T., Bratia Eugen a Ján Geromettovci v slovenskom národnom hnutí. Dizertačná práca, Banská Bystrica 2016.

Čenský, F., Z dob našeho probuzení. Sbirka prátelských dopisů, Praha 1875.

Dejiny Slovenska II (1526-1848), ed. V. Matula, Bratislava 1987.

Duchkowitsch, W., Serafínová, D., Vatrál, J., Dejiny slovenského novinárstva. Vývoj novinárstva na Slovensku v kontexte podunajskej monarchie, Ružomberok 2007.

Dvořák, R., "Snahy Františka Palackého o vydání české encyklopedie" [in:] Památník na oslavu stých narozenin Františka Palackého, ed. V.J. Nováček, Praha 1898, pp. 341-366.

Fišer, Z., “Profesor L'udovít Čulík a jeho slovenští žáci na gymnáziu v Přerově v letech 1875-1880: ke 120. výročí vzniku Jednoty českoslovanské podporující zájmy Slováků a Slovenska," Vlastivědný věstník moravský 2016, no. 3, pp. 238-252.

Fišer, Z., "Biografický přehled slovenských žáků na gymnáziu v Přerově v letech 18751916” [in:] Sborník Státního okresního archivu Přerov, ed. J. Lapáček, Přerov 2016, pp. 37-70.

Fišer, Z., Korespondence Aloise Vojtěcha Šembery, sv. 5: Listy slovenským prátelům, Vysoké Mýto 2007.

Fišer, Z., Dokumenty. 4. Korespondence Daniela Slobody s Jozefem Miloslavem Hurbanem, Brno 2009.

Lexikón české literatury. Osobnosti, díla, instituce, sv. 4/II: U-Z, ed. V. Forts, Praha 1993.

Hlasy Slováki̊v, Praha 1861.

Hlavačka, M. [et al.], České země v 19. století. Proměny společnosti v moderni době. II, Praha 2014.

Hurban, J. M., Gottšalk. Dějepisná pověst z IX. století, Praha 1861.

Hübner, K., Počtovanie na obrazoch, Praha 1872.

Hýbl, F., "Slovenští studenti na moravských středních školách v 19. století” [in:] Česko-slovenské vztahy v oblasti školství, ed. F. Hýb1, Přerov 1994, pp. 65-72.

Jarošová, A., "Prítomnost' češtiny na Slovensku a aspekt spisovnost," Jazykovedný časopis 2016, no. 1, pp. 5-25.

Kollár, J., Cestopis obsahující cestu do Horni Italie a odtud pres Tyrolsko a Bavorsko se zvláštním ohledem na slavjanské živly roku 1841 konanou a sepsanou od Jana Kollára, Praha 1862.

Kořalka, J., Češi v habsburskej řiši a v Evropě 1815-1914. Sociálněhistorické souvislosti vytvářeni novodobého národa a národostni otázky v českých zemích, Praha 1996.

Kubíček, J., Noviny a časopisy na Moravě a ve Slezsku do roku 1918. Literatura a prameny, sbirky, bibliografie, Brno 2001.

Kudzbelová, Z., "Prispievatel'ská činnost' J. M. Hurbana v (Riegrovom) Slovníku naučnom" [in:] Jozef Miloslav Hurban - osobnost'v spoločnosti a reflexii, eds. P. Macho, D. Kodajová, Bratislava 2017, pp. 251-264.

Osvald, S. A., Krát’učký prehl’ad dejín Slovenska od najstaršej až do najnovejšej doby pre l'ud obecný, Praha 1867.

Pasiar, Š., Dejiny slovenských l'udových knižnic, Martin 1957.

Pauliny-Tóth, V., Staré i nové piesne V. Podol'ského, Praha 1866. 
Pokorný, A., Dra A. Pokorného Obrázkový prírodopis všetkých troch ríš. Prvý diel, Obrázkový prírodopis živočišstva, Praha 1875.

Roubík, F., Časopisectvo v Čechách 1848-1862, Praha 1930.

Slovenský náučný slovník. I-III, ed. P. Bujnák, Bratislava 1932.

Slota, J., Jiřiho Sloty Rajeckého Básnické spisy, Praha 1882.

Skačanský, M., Jánošík, Praha 1880.

Sládkovič, A., Andreja Sládkoviča Spisy básnické, Praha 1878.

Strakovič, J. F., Krátke poučenie o hospodárstve a rolnictve, Praha 1864.

Tkadlečková-Vantuchová, J., Česi a Slováci v národnooslobodzovacom boji do rakúskouhorského vyrovnania roku 1867, Bratislava 1970.

Tkadlečková-Vantuchová, J., "K problematike československých vzt’ahov po rakúskomuhorskom vyrovnaní (1867)," Historický časopis 1970, vol. 18, no. 2, pp. 195-221.

Urban, J., Česká společnost 1848-1918, Praha 1982.

Urban, Z., "K česko-slovenským sbližovacím snahám v druhé polovině 19. Století” [in:] Pohl'ady na slovenskú politiku. Geopolitika - Slovenské národné rady - Čechoslovakizmus, ed. M. Pekník, Bratislava 2000, pp. 508-520.

Winters, S. B., "Sto let českého encyklopedismu (1860 - 1959): od F.L. Riegera a Jana Otty k T.G. Masarykovi a Bohumilu Němcovi," Časopis Matice moravské 2002, no. 2, p. 339-400. 